\title{
22 Impact of Methane Oxidation in Tropical Reservoirs on Greenhouse Gases Fluxes and Water Quality
}

Sandrine Richard, Philippe Gosse, Alain Grégoire, Robert Delmas and Corinne Galy-Lacaux

\section{Abstract}

This chapter presents a summary of water quality data (physico-chemical) from 10 years of measurements in the Petit Saut hydroelectric reservoir in French Guiana. Methane oxidation in and downstream of the reservoir are of particular interest. In the first part of the paper we discuss both the primary factors influencing the water quality and the patterns of stratification, methane production and oxidation in the reservoir. Secondly, we present data of methane emissions and oxidation downstream of the dam. We demonstrate that the oxidation of the dissolved $\mathrm{CH}_{4}$ was a major oxygen consumer downstream of the dam. The results indicate that the aerating weir built in the plant outlet canal guarantees the minimum regulatory concentration of $2 \mathrm{mg} \cdot \mathrm{L}^{-1}$ of dissolved oxygen as delineated by the scientific community of Petit Saut, following observations of the resistance to hypoxia in a tropical environment. This long term database, which helped in detecting changes over time (dissolved gases concentrations, $\mathrm{CH}_{4}$ oxidation velocity) will be used to improve the models developed to simulate both water quality and greenhouse gas emissions in a tropical reservoir environment.

\subsection{Introduction}

There are many large hydroelectric reservoirs located in tropical zones (Table 22.1). The corresponding impact studies must take into account the 


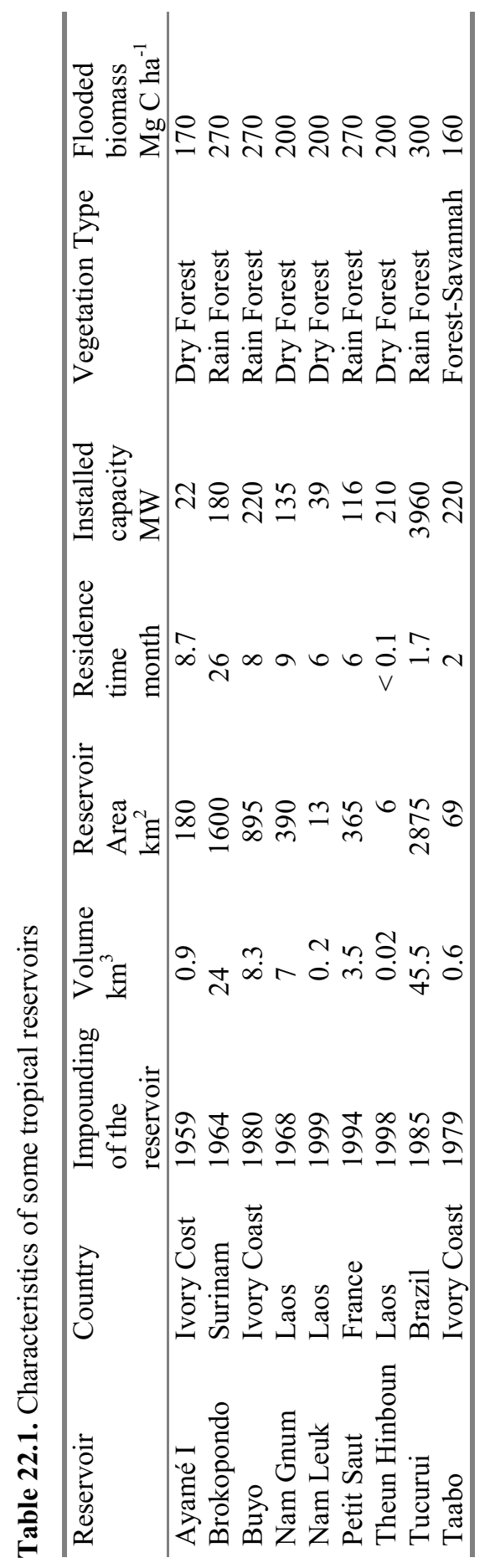


complexity and the fragility of the ecosystems of these regions, often covered by forests.

The vegetation biomass of a tropical rainforest can be dense, at Petit Saut reservoir studied in French Guiana (South America), it was estimated at $270 \mathrm{~T}(\mathrm{C}) \mathrm{ha}^{-1}$. Field measurements conducted on this reservoir since its impoundment in 1994 confirm that a tropical reservoir can be a significant source of carbon dioxide $\left(\mathrm{CO}_{2}\right)$ and methane $\left(\mathrm{CH}_{4}\right)$ due to the decomposition of this vegetation (Gagnon and Chamberland 1993; Svensson and Ericson 1993; Rosa and Shaeffer 1994; Galy-Lacaux et al. 1997a and b; Gosse et al. 2000).

The water quality results at Petit Saut - which are presented hereunder highlight the influence of methane which was responsible for a high oxygen consumption in the whole hydrosystem, including both the reservoir and the river downstream of the dam. The main consequence for the management of the power station was the accentuation of the deoxygenation observed from the beginning of the filling in the Sinnamary River downstream of the dam (Gosse and Grégoire 1997; Richard 1996). Electricité de France decided in September 1994 to build an aerating weir with two drops in the plant's tailrace canal, in order to bring atmospheric oxygen into the river and to emit into the atmosphere a high proportion (around $80 \%$ ) of oxygen-demanding dissolved methane. Operational since March 1995, the weir has enabled the power station to function continuously, while guaranteeing a minimum dissolved oxygen (DO) concentration of $2 \mathrm{mg} \mathrm{L}^{-1}$ in the downstream Sinnamary (Gosse et al. 2000; Richard et al. 2003).

\subsection{Site and Measurement Descriptions}

\subsubsection{The Example of the Petit Saut Reservoir and the Downstream River}

The Petit Saut dam is located on the Sinnamary River in French Guiana $\left(5^{\circ} 03 \mathrm{~N}, 53^{\circ} 02 \mathrm{~W}\right)$ (Fig. 22.1). It was constructed in the humid tropical forest by EDF's (Electricité de France) National Centre for Hydroelectric Engineering (CNEH). January 1994 marked the beginning of the filling phase. Full supply level, $35 \mathrm{~m}$ ASL (above sea level) in depth, was reached in June 1995; the reservoir stretches across approximately $365 \mathrm{~km}^{2}$ of inundated primary forest and has created $105 \mathrm{~km}^{2}$ of small islands. Its total storage capacity is $350010^{6} \mathrm{~m}^{3}$, useful storage is between 35 and $29.5 \mathrm{~m}$ ASL in depth, the minimum operating level. The total amount of flooded 


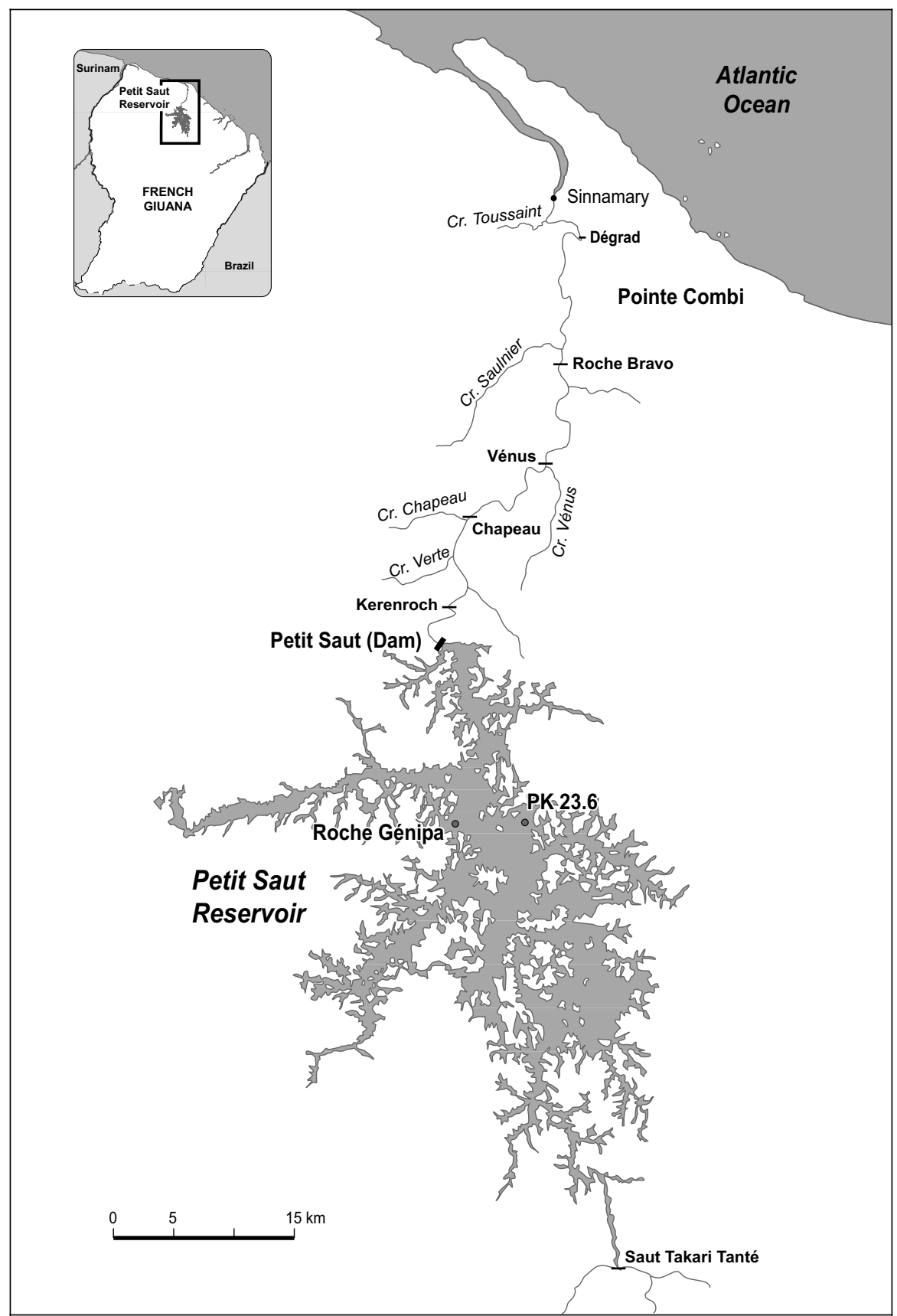

Fig. 22.1. Location of the main measurement stations in the Sinnamary drainage basin (French Guiana) 
biomass, including aboveground vegetation (170 $\left.\mathrm{T}(\mathrm{C}) \mathrm{ha}^{-1}\right)$ and soil $\left(100 \mathrm{~T}(\mathrm{C}) \mathrm{ha}^{-1}\right)$, is around 10 million tons of carbon. The average flow of the Sinnamary River at the dam site is close to $265 \mathrm{~m}^{3} \cdot \mathrm{s}^{-1}$. The retention time is approximately 6 months (Sissakian 1992). The installed capacity is $116 \mathrm{MW}$ generated by four $29 \mathrm{MW}$ turbine units. For this dam, the ratio between installed capacity and inundated area is therefore $0.32 \mathrm{MW}$ per $\mathrm{km}^{2}$ corresponding to $11.6 \mathrm{MW}$ per MT of carbon. In 1995, an aerating weir was built in the plant tailrace canal in order to improve air-water gas exchanges and to increase the oxygen content in the Sinnamary River (Gosse and Grégoire 1997; Gosse et al. 1997).

\subsubsection{Measurements}

Profiles of physico-chemical characteristics in the water column were measured since the impounding of Petit Saut (around 25 parameters such as conductivity, $\mathrm{pH}$, redox potential, temperature, mineral composition, dissolved organic carbon, total organic carbon, metals...). Additional campaigns were also conducted in 1995 on three reservoirs in the forested region of southern Ivory Coast (Buyo, Taabo and Ayame) Galy-Lacaux et al. 1999), and in 2001 and 2002 in East Asia (Laos) (Richard 2001a and 2002; Richard and Zouiten 2001). The average characteristics of Petit Saut (water flow and residence time, type of vegetation) compare quite well with those of some African and Asian reservoirs (Table 22.1).

Dissolved gas concentrations $\left(\mathrm{CH}_{4}\right.$ and $\left.\mathrm{CO}_{2}\right)$ were measured by the headspace technique in samples taken at various depths (MacKay and Shiu 1981). Analyses of gas concentrations were performed by gas chromatography using a flame ionization detector for $\mathrm{CH}_{4}$ and a thermal conductivity detector for $\mathrm{CO}_{2}$. Commercial standards with various concentrations adapted to the type of measurements were used for calibration. The reproducibility of the standards for each set of analyses was greater than $95 \%$.

Since the beginning of 1998, vertical profiles of dissolved oxygen and methane concentrations are regularly measured once or twice a month at a station located in the reservoir axis at $20 \mathrm{~km}$ from the dam (Roche Génipa), in order to follow the long-term evolution of these parameters.

Downstream, three stations are investigated: the turbines, the weir (downstream) and Pointe Combi (40 km downstream of the dam). 


\subsection{Water Quality and Methane Oxidation in the Reservoir}

The chemical and biochemical processes taking place at high temperatures in the lower layers of a tropical reservoir, in relation to the decomposition of the submerged biomass, leads to the formation of greenhouse gases $\left(\mathrm{CH}_{4}, \mathrm{CO}_{2}, \mathrm{H}_{2} \mathrm{~S}\right.$, etc). The consumption of oxygen resulting from these phenomena can maintain the lower layers of the lake in a permanent anoxic state, at least during the first few years after impounding. The thickness of the oxygenated surface layers may be reduced for several years (Fig. 22.2), despite the reoxygenation by atmospheric air or by phytoplankton photosynthesis.

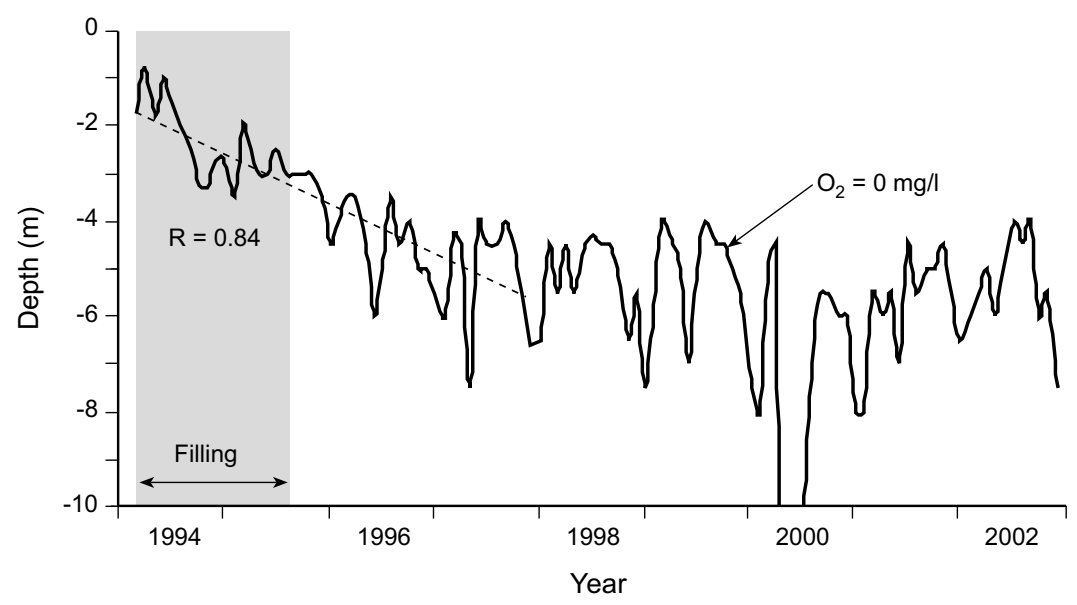

Fig. 22.2. Oxycline position in Petit Saut reservoir since impoundment

\subsubsection{Stratification and General Water Quality}

During the filling phase of Petit Saut reservoir (18 months), a stratified lake was formed in which the oxygenated upper layer gradually increased in thickness from less than $1 \mathrm{~m}$ at the beginning of the impoundment to close to $7 \mathrm{~m}, 5$ years later. The level of oxygen remained undersaturated at the surface, never exceeding $4 \mathrm{mg} \mathrm{L}^{-1}$ during the first five months; later, conditions improved and saturated oxygen was progressively measured $\left(8 \mathrm{mg} \mathrm{L}^{-1}\right)$ in the surface layer. High levels of dissolved oxygen are found during the dry season, when there is a maximum amount of sunlight and a high level of photosynthesis. 
The water column is still characterised by the complete absence of oxygen in the hypolimnion. This phenomenon appeared within 10 days after filling began and has continued with varying intensity. Temperature profiles show that the reservoir remains stratified almost throughout the year (Richard 1996; Richard et al. 1997 and 2000). We saw a partial destratification in May 2000, due to a major rise in the river discharge (around $\left.3000 \mathrm{~m}^{3} \cdot \mathrm{s}^{-1}\right)$.

From upstream to downstream in the reservoir, we can observe a longitudinal succession with a river zone, a transition zone and a lacustrine zone.

For all the parameters, a vertical gradient is only observed in the transition zone, the lacustrine zone, the axis of the lake (old river bed) and the coastal zones, because of the existence of a gradient between the bottom and the top of the lake. In the river zone, the water quality is the same as in the river but most of the vegetation is flooded at high water level. The transition zone is characterised by the presence of low concentrations of dissolved oxygen in the whole water column, and in the lacustrine zone, stratification is observed throughout the year with an oxygenated epilimnion (surface) and an anoxic hypolimnion (bottom). The measurements stations are mainly in the lacustrine zone.

This stratification was observed in several reservoirs located in South America: Brokopondo in Surinam (Leentvaar 1967, 1973, 1984 et 1993; Heide 1982), Samuel (Matsumara-Tundisi et al. 1989; Falotico 1993; Tundisi 1989; Figueiredo et al. 1994), Tucuruí (Champeau et al. 1986; Froehlich et al. 1993; Peireira 1994; Figueiredo et al. 1994), Curuá-Una (Junk et al. 1989; Darwish 1982) and Balbina in Brazil (Fearnside 1989; Eletronorte 1992 and 1993; Froehlich et al. 1993; Figueiredo et al. 1994). We observed the same type of stratification in Nam Leuk located in Laos (Richard 2001a and 2002; Richard and Zouiten 2001).

The high mean retention time (6 months at Petit Saut) maintains the thermal stratification (Darwish 1982). The large size of the reservoir has prevented the homogenisation of the whole water column. The hypolimnion is anoxic and enriched by the permanent diffusion of compounds due to organic degradation (i.e., ammonium, phosphate, dissolved organic carbon, methane) and matter released from the geological substrate (iron, manganese, silicon).

Conductivity can be selected as an indicator of the state of the reservoir. The mean conductivity ( 22 to $75 \mu \mathrm{S} \cdot \mathrm{cm}^{-1}$ ), since the start of the filling phase, has shown a general trend of enrichment, reaching its maximum level during the period from October 1994 to February 1995 (Fig. 22.3). The mineralization observed is very high, compared with other reservoirs 


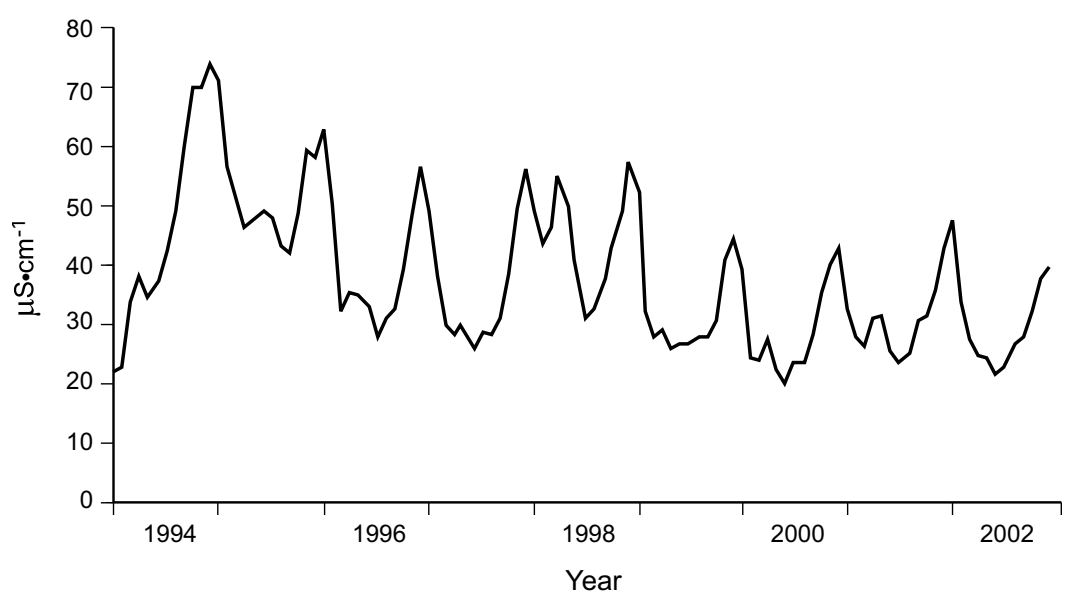

Fig. 22.3. Average conductivity $\left(\mu \mathrm{S} \cdot \mathrm{cm}^{-1}\right)$ in the water column of Petit Saut reservoir (central part) since impounding (time origin = January 1994)

like Samuel with a maximum of $45 \mu \mathrm{S} \cdot \mathrm{cm}^{-1}$ (Falotico 1993), Balbina with a maximum of $50 \mu \mathrm{S} \cdot \mathrm{cm}^{-1}$ (Eletronorte 1993; Froehlich et al. 1993) and Curuá-Una where the conductivity is less than $30 \mu \mathrm{S} \cdot \mathrm{cm}^{-1}$ (Darwish 1982; Junk et al. 1981). Following this period of maxima the values became more moderate. The enrichment was observed during each dry season, and from January through March 1998 due to exceptional climatic conditions associated with El Niño. The values reflect the opposing forces of production and variable dilution induced by rainfall. The bottom of the reservoir shows a high level of degradation. In the water column itself, a gradient between the bottom and the top of the lake is the result of dilution and bacterial consumption phenomena (Fig. 22.4) (Richard 1996; Richard et al. 1997). The values from the other reservoirs are substantially lower and could be explained by a difference in the period or the location of measurement level. We note, however, that their hierarchy corresponds to the ranking of the lakes according to the general organic matter retention times, as defined above.

The higher mineralisation at the bottom of the lake depends not only on production, but also on the dilution capabilities of the environment and the quantity of water capable of ensuring it. It is therefore related to the inflows of water that vary over time. The accumulation and decomposition of organic waste on the bottom lead to a modification in the physicochemical quality of the environment and its reactive capacities.

The $\mathrm{pH}$ decreased as soon as impounding began. This decrease is linked to the dissolving of the humic acids in the organic matter decomposed by 


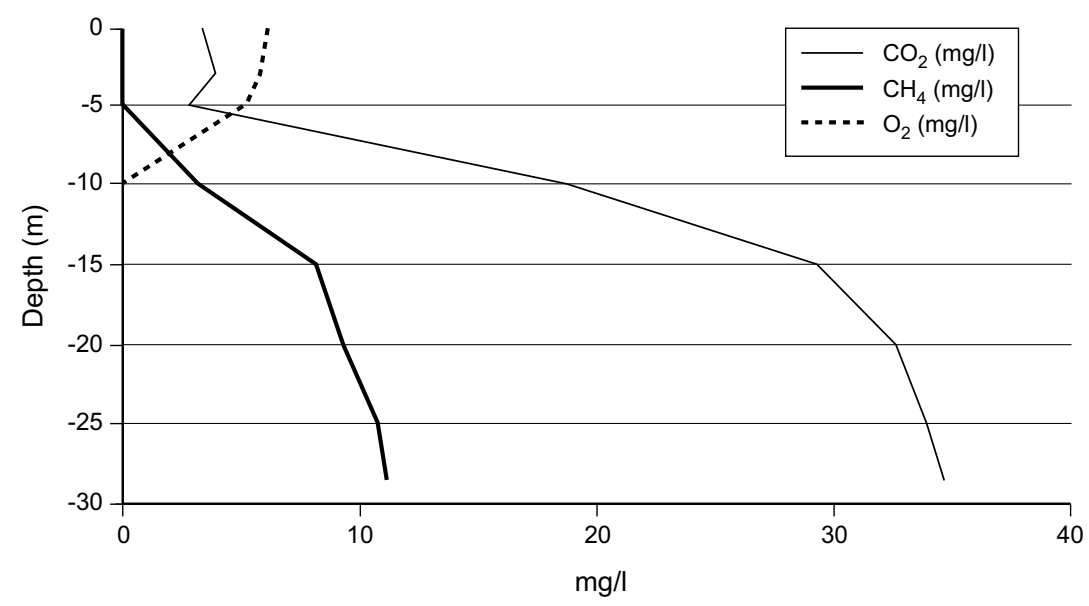

Fig. 22.4. Vertical profiles of dissolved oxygen, dissolved methane and carbon dioxide in Petit Saut reservoir in January 2002

respiration. Before the impounding, the mean value was 6.3. In the anoxic layer the mean value is around 5.6 in the reservoir of Petit Saut. At Brokopondo, most of the measurements range between 5.4 and 5.8 (Heide 1982), values in agreement with those found at Petit Saut.

At the base of the water column, the redox potential reaches low values, mostly inferior to 100 or $50 \mathrm{mV}$ and can, in certain circumstances, be negative. Redox potential is lower in the sediments. Concentrations of hydrogen sulphide have also been measured, with a maximum of $50 \mu \mathrm{g} \cdot \mathrm{L}^{-1}$ at the bottom in December 1994 (Lacaux et al. 1994a, b and 1995) and lower concentrations later (Dumestre 1998).

In the bottom layers of the reservoir, the high ammonium values correlated with the conductivity and the mean retention time and are an expression of the anaerobic decomposition process. The concentrations of ammonium measured at Petit Saut are close to those observed at Balbina (Electronorte 1993; Froehlich et al. 1993; Richard 1996).

The orthophosphate concentrations found at Petit Saut (maximum $3 \mu \mathrm{molP} \cdot \mathrm{l}^{-1}$ ) are the same as those found at Balbina (Eletronortre 1993). Falotico (1993) mentions maximum values of $0.4 \mu \mathrm{molP}^{-1}{ }^{-1}$ at Samuel, or 10 times less. The total phosphorus reached $12 \mu \mathrm{molP} \cdot \mathrm{l}^{-1}$ at Petit Saut, and did not exceed $3 \mu \mathrm{molP} .1^{-1}$ at Curuá-Una (Darwish 1982).

Given the anoxia on the bottom, the absence of nitrates and the very low sulphate concentrations, the role of electron acceptors necessary for biochemical degradation reactions is dominated by the metals with different degrees of oxidation, such as ferrous and manganitic derivatives (De Groot 
1991). This reduction results in more soluble derivatives whose accumulation is favoured not only by the changing redox balance, but also by the acidification of the environment. The phenomenon is even more perceptible when anoxia conditions are accentuated by the increase of the water retention time or the increase of the organic matter retention time. The results obtained at Curuá-Una (Darwish 1982) are mostly at the limit of detection. No metal dosing was carried out at Samuel (Falotico 1993). At Balbina, $\mathrm{Fe}^{2+}$ and $\mathrm{Fe}^{3+}$ concentrations were analyzed (Eletronorte 1993), with values reaching $11.3 \mathrm{mg} \cdot \mathrm{L}^{-1}$ for the $\mathrm{Fe}^{2+}$, like at Nam Leuk with $14 \mathrm{mg} \cdot \mathrm{L}^{-1}$, concentrations in the same range as those measured at Petit Saut.

The mobilization of the other components of the lateritic mineral substrate $(\mathrm{Si}, \mathrm{Al})$ is not directly linked to the redox potential modifications, but is highly dependant on the $\mathrm{pH}$, whose values are very close to the range of insolubility for the hydroxides corresponding to these elements. They therefore only participate in a very small manner in the mineralization of the bottom water.

\subsubsection{Methane Production and Oxidation in the Reservoir}

In Petit Saut reservoir, methane is produced in the sediment and probably in the water column (Dumestre 1998). Average concentrations of dissolved methane were calculated from profiles, with a linear interpolation between experimental points usually located at $0,3,5,10,15,20,25$ and $30 \mathrm{~m}$ of depth. Methane concentrations increased during the first months of reservoir impounding up to a maximum average value in the water column of $14 \mathrm{mg} \cdot \mathrm{L}^{-1}$ in the central part of the reservoir in May 1995, with a maximum of $24 \mathrm{mg} \cdot \mathrm{L}^{-1}$ at the bottom of the reservoir. At the same time, the oxygen concentration in the surface layer was undersaturated and lower than $4 \mathrm{mg} \cdot \mathrm{L}^{-1}$. Then periodical variations were observed. They are correlated with water flow variations in the reservoir inducing changes in the accumulation of dissolved gases (Galy-Lacaux 1996; Galy-Lacaux et al. 1997a and b). In French Guiana, the rainy season extends from December to July and the dry season from August to December.

After May 1995, the first minimum value of the mean dissolved methane concentration was observed in September 1995 (8.6 mg. $\left.\mathrm{L}^{-1}\right)$, followed by a maximum in January-February $1996\left(13 \mathrm{mg} \cdot \mathrm{L}^{-1}\right)$. The following minimum value was observed in April 1996. From December 1996 to January 1997, the average methane concentration was at a maximum of about $10 \mathrm{mg} \cdot \mathrm{L}^{-1}$. From April-June 1997, methane profiles indicated a sharp decrease in the average concentration in the reservoir reaching the lowest 
value ever observed (around $1 \mathrm{mg} \cdot \mathrm{L}^{-1}$ ). This minimum should be interpreted in light of the peculiar hydrology of the reservoir. It corresponds to a period of exceptionally high rainfall. Then after June 1997, concentrations increased slightly again and were equal to about $2 \mathrm{mg} \cdot \mathrm{L}^{-1}$ in August 1997. Later, an enrichment was observed each dry season, with two exceptional climatic events: in 1998 El Niño (a dry season within the rainy season), and in 2000, a major rising of the river (around $3000 \mathrm{~m}^{3} \cdot \mathrm{s}^{-1}$ ) (Fig. 22.5) (Richard et al. 2000).

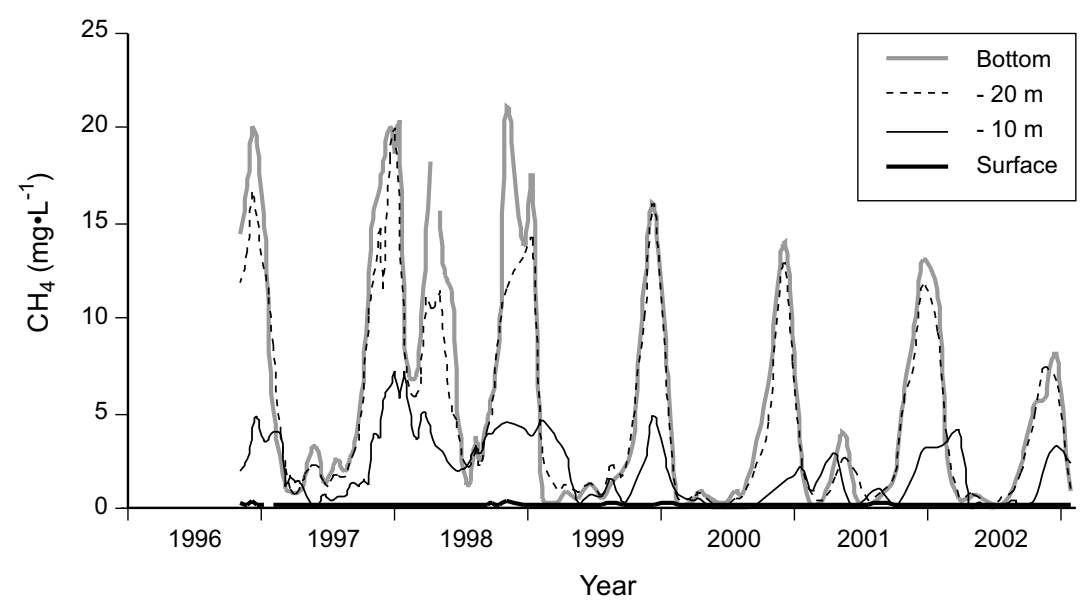

Fig. 22.5. Dissolved methane in Petit Saut reservoir (central part)

Using the 1994-1995 measurements and a vertical profile of methane measured in a comparable African reservoir which was 17 years old when it was sampled, an equation was proposed in 1996 to represent the evolution of average $\mathrm{CH}_{4}$ concentration in the water column of Petit Saut reservoir (near the dam) over the first 20 years:

$$
\mathrm{C}(\mathrm{t})=[10.5+3.5 \cos (2 \pi / 12) \mathrm{t}] \exp ^{-0.015 t}
$$

where $\mathrm{C}(\mathrm{t})$ is the dissolved methane in $\mathrm{mg} \cdot \mathrm{L}^{-1}$ and $\mathrm{t}$ is the time expressed in months (Fig. 22.6) (Galy-Lacaux et al. 1999). It is a rather acceptable formulation for the 1994-2002 period, when considering the methane fluxes in the water released by the dam (see Chap. 22.4.3). We observed a decrease in $\mathrm{CH}_{4}$ in March 1995 in the surface layer, due to its oxidation, in relation to the development of a high quantity of methanotrophic bacteria. These bacteria managed to stop definitely the diffusive methane emissions towards the atmosphere, with an associated significant consumption 


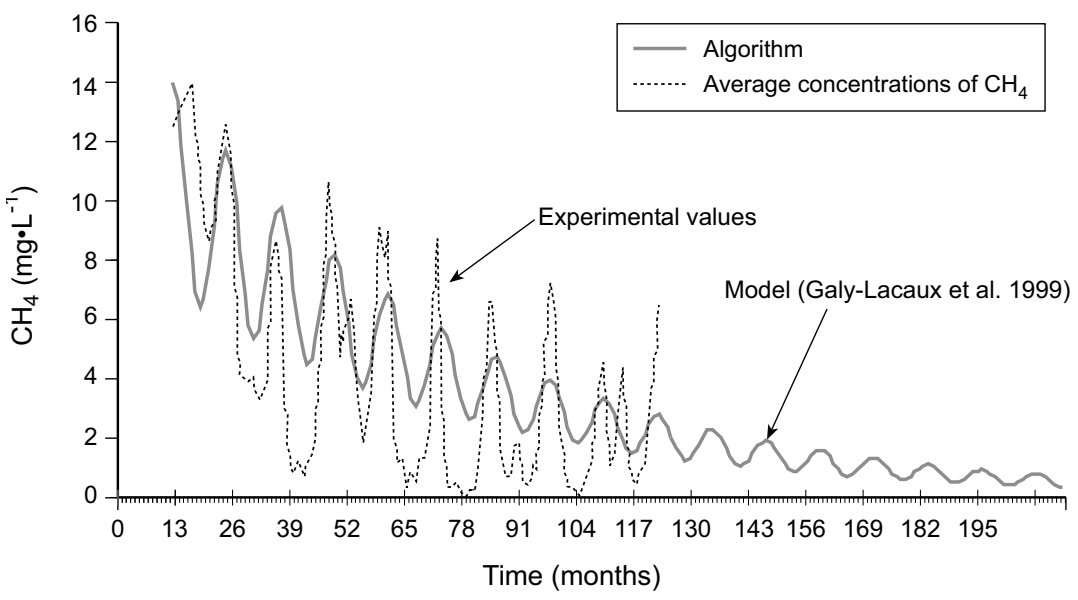

Fig. 22.6. Comparison between measured and predicted average concentrations of dissolved methane in the water column of Petit Saut reservoir (central part) since impoundment

of dissolved oxygen at the oxycline level (Dumestre 1998). In December 1995 , Dumestre measured a very high velocity $-0.27 \mathrm{mgCH}_{4} \cdot \mathrm{L}^{-1} \cdot$ hour $^{-1}-$ of methane oxidation at depth $-4 \mathrm{~m}$, which is a level of consumption much higher than previous published data (Dumestre 1998). Excessive illumination seems to have inhibited the growth of the methanotrophic bacteria during the first year after the beginning of filling (Dumestre et al. 1999a and b). The increase in the thickness of the surface oxygenated layer (less than $50 \mathrm{~cm}$ in 1994) following a decrease in other more classical oxidation processes progressively alleviated the effect of light when it reached $2 \mathrm{~m}$ at the end of 1994. Furthermore, the deepening of the oxycline offered more space for the development of methanotrophic bacteria which are aerobic under the oxycline, the accumulation of methane occurs during the dry season. It was roughly assessed that the dissolved oxygen consumption in the reservoir between 1995 and 1997 was around 0.3 Tg.year ${ }^{-1}$, including methane oxidation (which played a role from the second semester of 1994), activity of more classical bacteria (which started beginning of 1994), phytoplankton respiration and chemical consumptions (such as the transformation of $\mathrm{Fe}^{2+}$ in $\mathrm{Fe}^{3+}$ ).

A rather close relationship between methane concentrations and carbon dioxide is observed in the hypolimnion of Petit Saut reservoir (Fig. 22.7). When $\mathrm{CH}_{4}$ is equal to zero, the concentration of $\mathrm{CO}_{2}$ is around $13 \mathrm{mg} \cdot \mathrm{L}^{-1}$. This is the concentration close to that measured in flowing water in French Guiana rivers (around $20 \mathrm{mg} \cdot \mathrm{L}^{-1}$ ). 


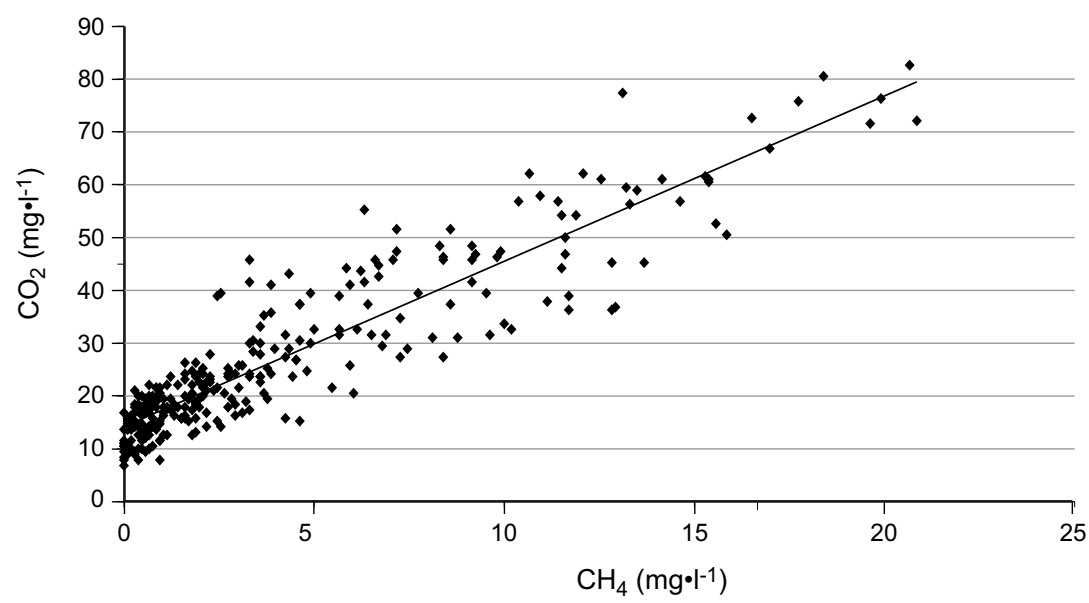

Fig. 22.7. Relationship between dissolved methane and carbon dioxide in the hypolimnion $(1998-2001)\left(\mathrm{CO}_{2}\right)=3.152\left(\mathrm{CH}_{4}\right)+14.32 \mathrm{r}=0.92$

Deoxygenation has also occurred, for example, in the reservoirs of Brokopondo, Nam Gnum and Ayamé, where, during the first years after their creation, the water bodies were of very poor quality (Heide 1982). They now have an epilimnion roughly fifteen meters thick that is well oxygenated and devoid of methane (Galy-Lacaux et al. 1999; Richard et Zouiten 2001).

\subsubsection{Principal Factors Influencing Water Quality}

The quality and quantity of submerged vegetation are also important factors in explaining the evolution of water quality. Hence, compared with Petit Saut, where the flooded vegetation is a "moist" type primary tropical forest, at Nam Leuk and Nam Gnum, it is the "dry" type with notably little leaf litter. At the Laotian sites a partial recuperation at the end of the rainy seasons is typical. Even more so, when reservoir is built in regions of savannah at these same latitudes, like at Taabo, the water quality problems are much less severe (Table 22.2). If the easily degradable forest litter, leaves and herbaceous plants provoke a rapid anoxia in the bottom layers, the tree trunks resist degradation for many long years. Junk and Nunes de Mello (1987) give degradation times between 10 and 100 years. Lake Brokopondo, 39 years after its impoundment, still has tree trunks in place, as does Nam Ngun impounded in 1968. The quality of the organic matter to be degraded is, therefore, an important factor that affects water quality, as well as the quantity of carbon. Hence, the consequences will be different if we flood a tropical primeval forest or a savannah. 
Table 22.2. Average concentration of dissolved $\mathrm{CH}_{4}$ on the vertical in different tropical reservoirs (close to the dam)

\begin{tabular}{lclll}
\hline Reservoir & $\begin{array}{l}\text { Age } \\
\text { years }\end{array}$ & $\begin{array}{l}\text { Sample } \\
\text { date }\end{array}$ & Season & $\begin{array}{l}\text { Average } \mathrm{CH}_{4} \\
\text { concentration } \\
\left(\mathrm{mg} \mathrm{L}^{-1}\right)\end{array}$ \\
\hline Buyo $^{*}$ & 15 & Dec.-95 & Beginning of dry season & 0.34 \\
Ayamé $_{\text {Nam Ngum }}^{* *}$ & 36 & Dec.-95 & Beginning of dry season & 0.38 \\
Nam Leuk $^{* *}$ & 34 & Apr.-01 & End of dry season & 0.10 \\
Nam Leuk $^{* *}$ & 2 & Apr.-01 & End of dry season & 7.57 \\
Nam Leuk $^{* * *}$ & 2 & Sept.-01 & End of dry season & 2.43 \\
\hline
\end{tabular}

* C. Lacaux et al. (1999)

*** Richard (2001a and b, 2002)

*** Richard (2002)

The availability and the renewal of dissolved oxygen is what will mainly determine the water quality in the reservoir (Goodland 1979; Tundisi 1988; Fearnside 1989). At Tucuruí, where the retention time is one month, the water quality remains acceptable. Stratification of the central zone only takes place during low flow periods. During this period, the hypolimnion is anoxic. During the rainy season, the whole water body in the central zone is oxygenated and the bottom layers in the littoral zone remain anoxic (Pereira 1989 and 1994). At Curuá-Una where the renewal time is low (1 month), Darwish (1982) carried out a surveillance program from November 1977 to May 1978. The most unfavourable station presented oxygenation conditions from the surface to the bottom during the last two months of the study, but the concentrations remained low $\left(0.5 \mathrm{mg} \mathrm{L}^{-1}\right)$. Junk et al. (1981) indicated that the stratification of CuruáUna was not pronounced, and no oxygen was present at the surface during their measurements. Amazonian reservoirs in general don't present marked temperature gradients on the vertical, but this doesn't make the thermocline more fragile, as the temperatures are high.

Junk et al. (1981) and Darwish (1982) indicated that $63 \%$ of the dissolved oxygen in the Curuá-Una reservoir had come from surface diffusion, $27 \%$ from the upstream tributaries and $10 \%$ from primary production. At Petit Saut, it was assessed that, between 1995 and 1997, the oxygen input into the reservoir was around $0.3 \mathrm{Tg} \mathrm{year}^{-1}$, with rather comparable fluxes from primary production and surface diffusion $\left(0.1-0.15 \mathrm{Tg} \mathrm{year}^{-1}\right)$ and a flux of $0.05 \mathrm{Tg}_{\mathrm{gear}}{ }^{-1}$ from upstream tributaries (Gosse et al. 2000). It is important to note that the presence of dissolved oxygen in the epilimnion not only depends on the primary production, wind, currents and 
aeration, but also on the reservoir's morphology and the amount of water flowing into the lake. An hypolimnion, rather independent from the epilimnion (the oxygen does not diffuse), can persist in case of a moderate renewal by inflows from the tributaries, as occurs in the central part of Petit Saut reservoir where there is an absence of total destratification. The permanence of the stratification is shown by Heide (1982) at Brokopondo. This author also attributes this absence of mixing to the presence of flooded trees that impede the action of the wind. Manosowski (1986) and Paiva (1977) have also demonstrated this phenomenon. These conditions can favour the development of macrophytes that may react, in turn, to the influence of the wind and the circulation of water.

The retention time of waters in the reservoir is an essential parameter in the comprehension of the phenomena occurring in reservoirs, but it is important to associate it with other parameters such as reservoir morphology and bathymetry, and spatial circulation and turbulence in the different zones of the lake. The Petit Saut reservoir, like all of the Amazonian reservoirs, is heterogeneous. It is made up of zones with variable retention times, averaging 6 months for the whole of the reservoir. Certain zones have long renewal times (up to 14 months at Crique Aimara and 27 months at Crique Bonne Nouvelle, according to Sissakian 1992). Even though each zone may react in a different manner, the depth of the epilimnion appears to be rather uniform spatially. It should be noted that the dendritic pattern of reservoirs affects the circulation and the renewal of water. The passage of water coming from tributaries takes place in a preferential manner in the axis of the former riverbed. This phenomenon is also described by Leentvaar (1966) and Heide (1982) at Brokopondo. At Theun Hinboun, the intense renewal of the water body does not lead to dissolved oxygen problems in the reservoir, 3 years after its creation, despite an initial biomass in the reservoir area (identical to Nam Leuk).

On the basis of carbon production measurements performed by Vaquer et al. (1997), the input of carbon by phytoplankton growth was close to $0.03 \mathrm{Tg}$ year $^{-1}$ in Petit Saut reservoir (Gosse et al. 2000). It is comparable to the organic part $\left(0.02 \mathrm{Tg}\right.$ year $\left.^{-1}\right)$ of the poorly labile carbon flux coming from the upstream tributaries and ten times lower than the gaseous emission of carbon $\left(\mathrm{CH}_{4}\right.$ and $\left.\mathrm{CO}_{2}\right)$ to the atmosphere assessed by Galy-Lacaux et al. (1997) for the 1994-1997 period. This shows the importance of carbon production coming from the submerged soil in the first years after filling.

The emissions of methane and dissolved carbon dioxide towards the atmosphere arise from three different processes: diffusion at the lake surface, gas bubble flux in shallow zones of the lake, and water degassing downstream from the dam. The last process is examined in the next chapter. 


\subsection{Methane Emission and Oxidation Downstream of the Reservoir}

The early hypothesis (Gosse 1994) of a major contribution of dissolved methane (DM) in the dissolved oxygen (DO) sink observed in the downstream river during the turbining tests was proven (Chap. 22.4.1). It justified the building of an aerating weir in the plant outlet canal (Chap. 22.4.2). Operational since March 95, the weir allows an immediate reoxygenation of the water and a significant local elimination of methane towards the atmosphere. Thanks to the weir, over $2 \mathrm{mg} \mathrm{L}^{-1}$ of DO is maintained in the river at Pointe Combi, the minimum regulatory concentration set in conjunction with the Scientific Committee, following observations made on the resistance of fish to hypoxia in a tropical environment.

The oxidation of the residual DM and other compounds released by the dam, and the low inflows of the downstream tributaries led to the formation in the downstream river (from the dam outlet confluence down to the estuary) of a DO sag curve whose minimum was mainly located between Roche Bravo (31 km downstream of the dam) and Pointe Combi (40 km) over the March 1995-2000 period. The downstream DM concentrations observed at Petit Saut and their contribution to the atmospheric methane emissions and the DO budget of the downstream river are detailed in Chap. 22.4.3 to 22.4.8.

The analysis of dissolved gases along the river, downstream of new tropical dam lakes, have rarely been the subject of such in-depth research, especially for methane. Some DO data were collected: at Balbina, Eletronorte (1993) found that the downstream DO did not reach $1 \mathrm{mg} \cdot \mathrm{L}^{-1}$ and that the situation was improving $200 \mathrm{~km}$ downstream, at the confluence with Rio Jatapu. At Curuá-Una, characterised by a low renewal time (1 month), a DO content greater than $5 \mathrm{mg} \cdot \mathrm{L}^{-1}$ was measured during the November 1977-May 1978 (Darwich 1982).

\subsubsection{Evidence of a Consumption of Dissolved Oxygen in the Downstream Sinnamary River Due to an Oxidation of Dissolved Methane}

The significant role of dissolved methane (DM) oxidation on the dissolved oxygen (DO) balance of the river downstream from the Petit Saut dam, was demonstrated in 5 chronological steps (Gosse et al. 2000): 


\section{Evidence in June-August 1994 of an Oxygen Demand of Gaseous Origin Added by the Turbined Water into the Downstream River}

Before the first testing of the hydroelectric plant turbines in June 1994, the guaranteed instream flow of around $100 \mathrm{~m}^{3} \cdot \mathrm{s}^{-1}$ was released exclusively by the bottom gates. Although the mean DO concentration in the reservoir had been close to zero since February 1994, the DO concentration in the whole downstream Sinnamary was exceeding $4 \mathrm{mg} \cdot \mathrm{L}^{-1}$ (Fig. 22.8): the reason was the atmospheric equilibrium of DO (close to $8 \mathrm{mg} \cdot \mathrm{L}^{-1}$ at $25^{\circ} \mathrm{C}$ ) obtained immediately downstream of the jet and the hydraulic jump generated at the gates outlet. On the contrary, without air mixing, the DO concentration was nil in the turbined water and in the plant outlet canal which enters the river $300 \mathrm{~m}$ downstream. The surprise came from the high amount of dilution flow which had to be released by the bottom gates to exceed $2 \mathrm{mg} \cdot \mathrm{L}^{-1}$ of DO at Pointe Combi during the turbining tests. It was shown by a DO model (Gosse, 1994) that the only way to correctly reproduce the observed DO profiles in the river was to consider that the 2 day DO demand in the turbined water was greater than in the bottom gates outlet, with a difference progressively increasing from at least $2.5 \mathrm{mg} \cdot \mathrm{L}^{-1}$ in mid-June 1994 to close to $10 \mathrm{mg} \cdot \mathrm{L}^{-1}$ end of August-beginning of September 1994. As the turbine inlet from the reservoir is a few metres above the inlet of the bottom gates, and as the survey in the reservoir at the time (Richard, 1996) was revealing poorer chemical conditions with increasing depth, it was considered (Gosse 1994) that this additional DO demand in the turbined water could only be of gaseous origin and generated in the deoxygenated reservoir, and that - thanks to the high local air-water mixing the gaseous DO demand downstream of the bottom gates had been low.

\section{Theoretical Assessment - Early September 1994 - of a DM Concentration of Several $\mathrm{mg} \cdot \mathrm{L}^{-1}$ in the Turbined Flow End of August-Beginning of September 1994}

Without any measurement of reduced gases, DM role was the more convincing assumption for explaining such a high gaseous DO demand, as excessively higher concentrations had to be considered for the other potential candidate $\mathrm{H}_{2} \mathrm{~S}$ (Gosse 1994; Gosse and Grégoire 1997). This proposal came as a surprise to the GHG team whose last measurements resulting from samples taken in March 1994 were indicating a mean level of DM in the reservoir of only $0.3 \mathrm{mg} \cdot \mathrm{L}^{-1}$. 


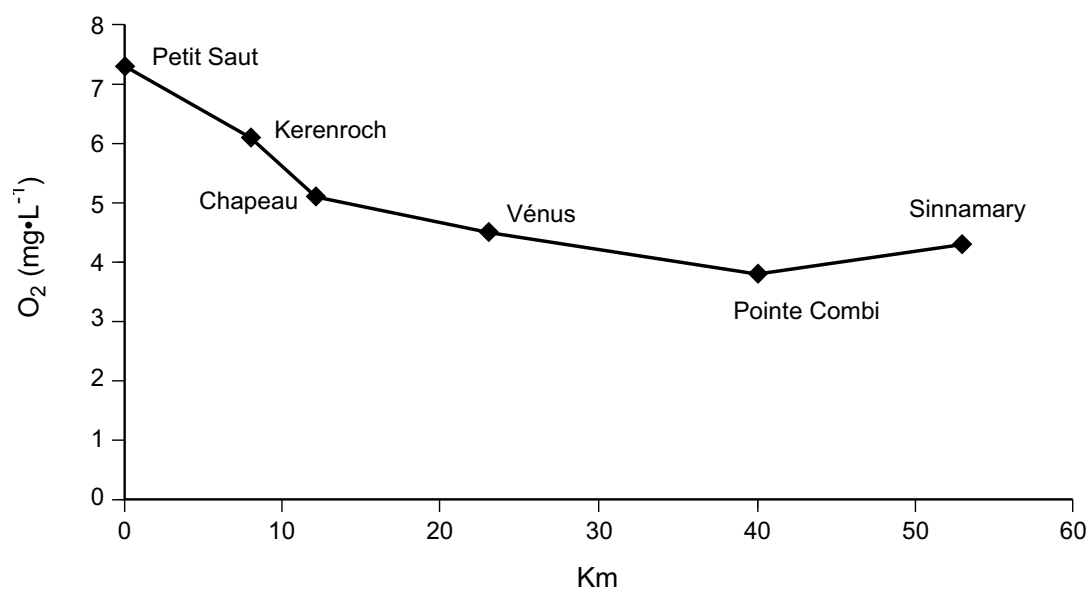

Fig. 22.8. Longitudinal profile of dissolved oxygen $\left(\mathrm{mg} \cdot \mathrm{L}^{-1}\right)$ in Sinnamary Estuary from the dam to the estuary entrance, end of March 1994

\section{Experimental Confirmation of DM Presence End of September 1994}

Galy-Lacaux (1996) measured a high concentration $\left(3 \mathrm{mg} \cdot \mathrm{L}^{-1}\right)$ of DM in the turbined water and a very low concentration $\left(0.2 \mathrm{mg} \cdot \mathrm{L}^{-1}\right)$ downstream of the bottom gates in the samples taken beginning of September 1994.

\section{Experimental Confirmation - from October 1994 - of a DO Sink of Gaseous Origin Contained in the Bottom Layers of the Reservoir and in the Turbined Water}

The method applied by (Richard 1996) consisted in comparing the consumption of DO in bottles containing either unagitated water or water having being strongly agitated to establish a gaseous equilibrium with the atmosphere. Gaseous DO consumption was mainly observed in less than one and a half days.

\section{In situ Measurements - from December 1994 to September 1995 - Proving Rapid DM Oxidation in the River}

Galy-Lacaux (1996) and Galy-Lacaux et al. (1997) firstly showed that all the DM present in the water downstream of the dam had disappeared at Pointe Combi, and secondly - using emission measurements by gas chambers - calculated that no much more than $20 \%$ of the DM present in the Sinnamary $300 \mathrm{~m}$ downstream of the dam was emitted to the atmosphere along the $40 \mathrm{~km}$. That proved the predominance of the oxidation of DM in 
the progressive disappearance of DM downstream of the weir. It was also a confirmation of the high speed of DM oxidation in the downstream river, as between one day and two days are necessary for a water body released at the dam to travel $40 \mathrm{~km}$, for a discharge between $240 \mathrm{~m}^{3} \cdot \mathrm{s}^{-1}$ and $100 \mathrm{~m}^{3} \cdot \mathrm{s}^{-1}$. The involvement of methanotrophic bacteria in the DM oxidation was shown in 1996 by J. F Dumestre (1998).

\subsubsection{Building of an Aerating Weir in the Plant Outlet Canal in Order to Guarantee $2 \mathrm{mg} \mathrm{L}^{-1}$ of DO in the Downstream Sinnamary River}

To honour the minimum requirement of $2 \mathrm{mg} \cdot \mathrm{L}^{-1}$ during the turbining tests, it was necessary in September 1994 to dilute the turbined flow by a discharge from the bottom gates four times greater. It was not a viable situation for a normal exploitation of the hydroelectric plant, which had to come into service in 1995. Consequently, EDF decided at end of September 1994 to build an aerating weir in the outlet canal in order to create an exchange of gases (oxygen and methane) between air and water, taking the entire technically possible head (Gosse and Grégoire 1997). The weir (Fig. 22.9) is a $85 \mathrm{~m}$ wide cascade of 2 consecutive waterfalls. It is a metallic structure of 5 hexagons ( downstream walls, the top of which is $5.8 \mathrm{~m}$ and $3.4 \mathrm{~m}$ above sea level, respectively.

The weir, installed in March 1995 showed a good aeration efficiency, with close to $80 \%$ of the DM eliminated from the turbined water and a DO concentration immediately downstream of the weir close to $90 \%$ of the saturation level for turbined discharge up to $200 \mathrm{~m}^{3} \cdot \mathrm{s}^{-1}$. This aeration efficiency decreased after December 2001 due to a voluntary reduction in the height of the upper wall (and therefore the upper nappe) in order to better satisfy the higher electricity demand. The lowering of the weir was possible as higher margins above the DO threshold of $2 \mathrm{mg} \cdot \mathrm{L}^{-1}$ were observed in the downstream Sinnamary, due to a decrease of the DO demand in the river. Some characteristics of the aerating efficiency of the weir are given here under. More details on the weir structure and its efficiency can be found in Gosse and Grégoire (1997), Gosse et al. (1997b) and Richard et al. (2003). 


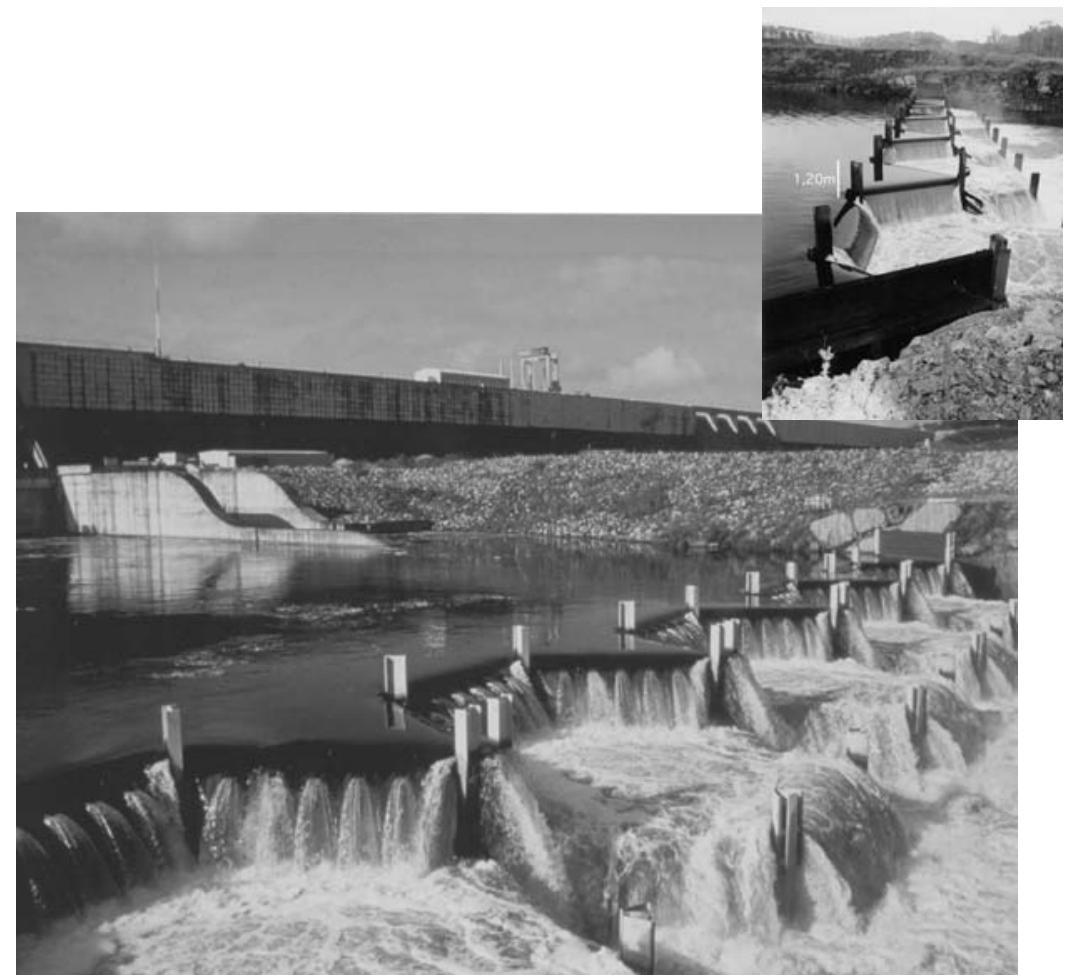

Fig. 22.9. Aerating weir in the power plant outlet canal before and after its first lowering

\subsubsection{Historical Reconstruction (1994-2002) of the DM Concentrations and Fluxes in the Water Crossing the Dam}

Over the years, between 1994-2002, the flow crossing the dam was mainly turbined or passed through the bottom gates. DM concentrations in the reservoir at the intakes of the turbine circuit and the bottom gates are close, with a difference in altitude of only a few metres between the two intakes. There is only a slight difference in the concentration of non volatile compounds observed in the near downstream of the corresponding outlets.

DM concentrations in the water intake of the dam can be determined by 3 methods: direct DM measurement in the water entering the turbines (with some uncertainty due to the heterogeneity to be considered from one turbine to another) when the plant is running; DM measurement in the first hectometres downstream of the dam which gives the water intake concentration, if the percentage of DM elimination to the atmosphere at the im- 
mediate outlet of the dam has been correctly assessed; exploitation of DM concentrations measured in the reservoir along a vertical in the central part near the dam (Galy Lacaux et al. 1997-1999 and Delmas et al. 2001 chose this last method and the average value for their GHG emissions forecasts).

The first method is favoured here, as a lot of DM data were collected in the turbine entrances (weekly step in 1995, 15 days step from 1996 to 1998 , monthly step the following years) and as the method is more representative of the flow released by the dam, which was mainly turbined and released by the bottom gates during the 9 years.

2 types of special events must be considered however:

- the use of the surface valve from March 1995 till October 1996 in order to inject a partial flow of better water quality into the plant outlet canal. The DM concentration in this outlet was representative of the surface of the reservoir. But the discharges involved were low.

- the use of the flood gates, for the rare floods which were too strong to be evacuated only by the bottom gates.

If we assume that the impact of the slightly higher DM concentrations in the bottom gates - by comparison to the turbine circuits - is compensated by the impact of the lower DM concentrations appearing when the upper flood gates are used, DM concentrations and DM fluxes in the water crossing the dam can be assessed by using the DM concentrations measured in the turbines entrance (given in Fig. 22.10): by multiplying for each month of the March 1995-December 2002 period, the average value of DM measurements in the turbine entrance by the corresponding monthly discharge released by the dam, we find that DM concentrations and DM fluxes in the water crossing the dam were respectively equal to $4.75 \mathrm{mg} \cdot \mathrm{L}^{-1}$ and $1.1 \mathrm{~kg} \cdot \mathrm{s}^{-1}$ on average over the 94 months (mean annual flow close to $\left.250 \mathrm{~m}^{3} \cdot \mathrm{s}^{-1}\right)$.

The average DM concentration and the DM flux in the water crossing the dam become respectively equal to $4.7 \mathrm{mg} \cdot \mathrm{L}^{-1}$ and 290000 tons $\left(1.03 \mathrm{~kg} \cdot \mathrm{s}^{-1}\right)$ over the 1994-2002 period, including the first 14 months characterized by the following increase in DM concentrations: $0 \mathrm{mg} \cdot \mathrm{L}^{-1}$ in January 1994, $0.25 \mathrm{mg} \cdot \mathrm{L}^{-1}$ in March (GHG team measurement in the reservoir), $0.8 \mathrm{mg} \cdot \mathrm{L}^{-1}$ in June 1994 (Gosse 1994), $3 \mathrm{mg} \cdot \mathrm{L}^{-1}$ in September (GHG team measurement), and $12-14 \mathrm{mg} \cdot \mathrm{L}^{-1}$ range over the December 1994February 1995 period (GHG team and Hydreco measurements).

A slightly greater flux - 340000 tons $\left(1.2 \mathrm{~kg} \cdot \mathrm{s}^{-1}\right)$ - is obtained over the same period when replacing the 1995-2002 DM measurements by the Galy Lacaux (1996) sinusoidal function given in Chap. 22.3 .2 (with $t=0$ corresponding to 1 January 1995). This formula was used in the previous 


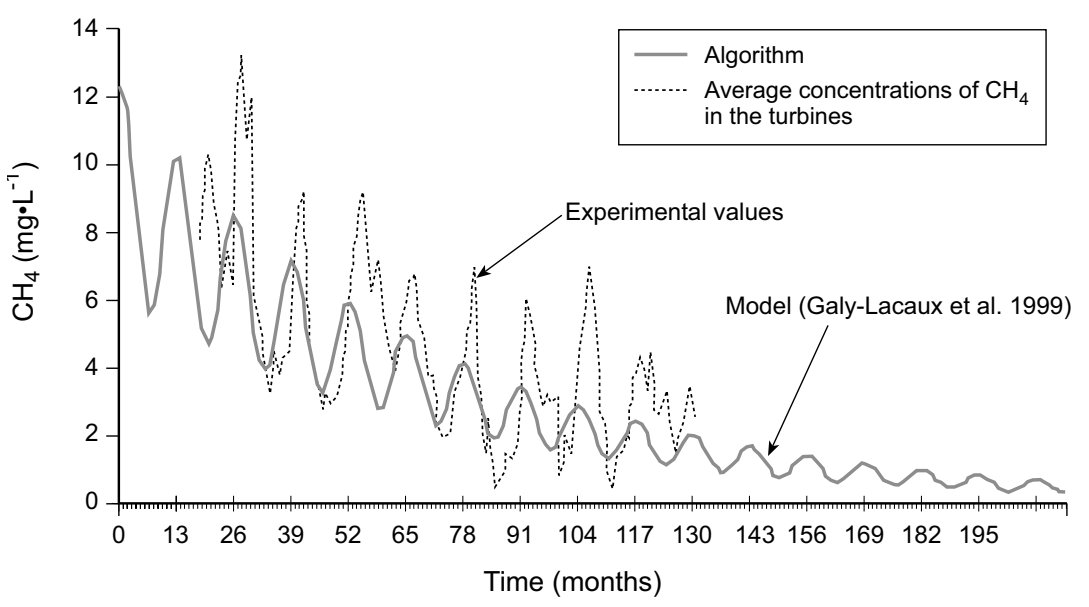

Fig. 22.10. Comparison of the Galy-Lacaux et al. algorithm with the average monthly concentrations of dissolved $\mathrm{CH}_{4}\left(\mathrm{mg} \cdot \mathrm{L}^{-1}\right)$ measured in the turbines entrance (time origin $=$ January 1994)

downstream GHG forecasts calculated by Galy Lacaux et al. 1997-1999 and Delmas et al. 2001 who proposed a mean downstream DM flux of 395000 tons $-1 / 3$ greater than the flux based on measurements - the surplus being mainly due to the difference between the predicted and the real flow discharges downstream of the dam.

\subsubsection{Efficiency of DM Elimination in the Near Downstream of the Dam (1994-2002)}

In the very near downstream of the dam, significant amount of DM contained in the flow crossing the dam can be emitted to the atmosphere by aeration processes taking place either at the outlet of the bottom gates or at the weir built in the plant outlet canal.

For a good assessment over the 1994-2002 of this local elimination, it is necessary to consider 4 periods:

- from Januray 1994 (beginning of reservoir filling) until March 1995, period during which there was no aerating weir in the plant outlet canal. The bottom gates and - episodically - the turbine circuits (during the short turbine tests of the June-September 1994 period) were used.

- from March 1995 (aerating weir on operation) till October 1996, period during which the flow was mainly turbined, but with some small addition from the bottom gates or the surface valve at the dry seasons in 
order to guarantee $2 \mathrm{mg} \cdot \mathrm{L}^{-1}$ of DO in the downstream river. But the potential benefit of the surface valves was limited for DM, as these valves release the flow into the plant outlet canal immediately upstream of the aerating weir.

- from October 1996 till December 2001, period during which the flow was turbined normally, under the initial configuration of the aerating weir.

- from end of December 2001 till December 2002, period during which the flow was turbined normally, under a new configuration of the aerating weir (division roughly by 2 of the height of the upper fall due to a lowering of $1.2 \mathrm{~m}$ of the top of the upper wall)

For the last 3 periods, the bottom gates (and exceptionnaly the flood gates) were also used to release the peak discharges entering the reservoir.

\section{Aeration Efficiency at the Bottom Gates Outlet}

For a discharge of $100 \mathrm{~m}^{3} \cdot \mathrm{s}^{-1}$ released by the dam through the bottom gates, it can be assumed that around $95 \%$ of the DM contained in the water is emitted to the atmosphere in the air-water mixing taking place at the outlet: in September 1994, the outlet DM concentration was around $0.15 \mathrm{mg} \cdot \mathrm{L}^{-1}$ for an average value of $3 \mathrm{mg} \cdot \mathrm{L}^{-1}$ in the turbine outlet; at the end of February 1995, the outlet DM concentration was $0.45 \mathrm{mg} \cdot \mathrm{L}^{-1}$ for a value exceeding $8 \mathrm{mg} \mathrm{L}^{-1}$ in the turbine entrance.

\section{Aeration Efficiency of the Weir Built in the Plant Outlet Canal}

It was experimentally assessed in 1996 that, for a discharge released by the dam through the turbines, the weir was eliminating $82 \%$ of the DM contained in the water at $80 \mathrm{~m}^{3} \cdot \mathrm{s}^{-1}$ and $75 \%$ at $230 \mathrm{~m}^{3} \cdot \mathrm{s}^{-1}$, the upstream concentration of DM being around $5 \mathrm{mg} \cdot \mathrm{L}^{-1}$ (Gosse and Grégoire 1997). The use of the monthly uptream and downstream measurements taken in 1999 and 2000 gives a slightly better aeration efficiency, with a percentage of elimination of $80 \%$ on average (standard deviation of $3 \%$ ) for a discharge in the $160-270 \mathrm{~m}^{3} \cdot \mathrm{s}^{-1}$ range and upstream DM concentrations varying from 2 to $7 \mathrm{mg} \cdot \mathrm{L}^{-1}$. The lowering of the upper fall in December 2001 led to a decrease in the efficiency of DM elimination close to $10 \%$ (Richard et al. 2003). Over the year 2002, the monthly upstream (turbine entrance point) and downstream $(0.8 \mathrm{~km}$ downstream of the dam) DM concentrations give a mean percentage of DM emission to the atmosphere equal to $68 \%$, whereas the percentage was equal to $79 \%$ over the 3 years 1999-2001. 


\section{Global Efficiency of DM Elimination in the Near Downstream of the Dam}

For an assessment of the percentage of DM eliminated in the near downstream of the dam under aeration processes, it has to be considered, firstly, that the efficiency of DM elimination decreases when the discharge increases, secondly, that a release of water both through the gates and the weir affect the elimination efficiency at the 2 sites as the downtream altitude of the river is dependent on the total discharge released at the dam (the moderate secondary effect of the tide is disregarded). However, a situation with outlet daily and monthly discharges outside the (turbined) range $150-270 \mathrm{~m}^{3} \cdot \mathrm{s}^{-1}$ is not frequent since June 1995 (end of the first filling of the reservoir). Much higher discharges leading to the opening of the bottom gates can be observed during the high peak of the rainy season, mainly in May or June: in June 1999 and May 2000, for a turbined discharge of $250 \mathrm{~m}^{3} \cdot \mathrm{s}^{-1}$ in both cases, and a bottom gates discharge of respectively 400 and $300 \mathrm{~m}^{3} \cdot \mathrm{s}^{-1}$, it was measured that there was respectively $57 \%$ and $60 \%$ less DM in the near downstream of the river-plant outlet canal confluence than in the water entering the turbines circuits.

Using daily discharges crossing the dam through the different outlets and aeration efficiencies of the 2 main aerating structures (bottom gates and aerating weir) at those discharges, it can be assessed that close to $80 \%$ of the DM flux released by the dam over the 1994-2002 period was emitted to the atmosphere immediately downstream of the dam.

It is a greater value than the percentage of $\mathrm{CO}_{2}$ emitted to the atmosphere under the same aeration processes: according to the monthly values collected by Hydreco, this percentage was close to $65 \%$ on average on the 3 years $1999-2001$, with a mean $\mathrm{CO}_{2}$ concentration close to $20.5 \mathrm{mg} \cdot \mathrm{L}^{-1}$ in the turbine entrance -6.6 times the mean DM concentration - and close to $13.5 \mathrm{mg} \cdot \mathrm{L}^{-1}, 0.8 \mathrm{~km}$ downstream of the dam. The 6.6 ratio between DM and dissolved $\mathrm{CO}_{2}$ in the flow crossing the dam is lower than the ratio obtained between $\mathrm{CO}_{2}$ and DM by Galy-Lacaux et al. (1999) and Delmas et al. (2001), in their prediction of outlet fluxes from the dam over 20 years (Table 12.1, chap. 12). The ratio is 14 , based on a formula - given in chap. 12 - determining $\mathrm{CO}_{2}$ fluxes from $\mathrm{CH}_{4}$ values. However, it does not mean that their forecast of downstream $\mathrm{CO}_{2}$ emissions by Petit Saut dam (Table 12.1) are significantly overestimated. $\mathrm{CO}_{2}$ emissions to the atmosphere which take place in the downstream Sinnamary and are not linked to DM oxidation have also to be taken into account. The joint HydroQuébec - Hydreco - CNRS - EDF campaign performed in May 2003 shows that these emissions are high. 


\subsubsection{DM Emissions to the Atmosphere in the Sinnamary River Downstream of the Aerating Weir}

Downstream of the weir built in the plant outlet canal, the proportion of DM emitted to the atmosphere could not be very high during the first years following the reservoir impoundment for 2 main reasons:

- rapid oxidation of DM accelerating the disappearance of DM in the water, limiting the DM stock which can be emitted to the atmosphere downstream

- unfavourable physical conditions for an important exchange of gases at the water-air interface in the first $20 \mathrm{~km}$ : low slope of the bed (less than $0.003 \%$ ), deepness of the river - the mean depth between the weir and Pointe Combi can be approached by the formula $\mathrm{H}=1.56 \mathrm{Q}^{0.193}$ with $\mathrm{Q}$ discharge crossing the dam in $\mathrm{m}^{3} \cdot \mathrm{s}^{-1}$ - and very low winds usually.

Galy-Lacaux (1996) and Galy-Lacaux et al. (1997a) assessed that only around $20 \%$ of the DM remaining in the river immediately downstream of the weir was escaping to the atmosphere between the weir and Pointe Combi. The asssesment was based on measurements of gas emissions to the atmosphere performed in 1995 by the GHG team, with a closed chamber drifting along the river. 2 discharges were studied: $220 \mathrm{~m}^{3} \cdot \mathrm{s}^{-1}$ in 5 sections of the river between the aerating weir and Crique Venus $(23 \mathrm{~km}$ downstream of the dam) in September 1995 (Galy-Lacaux 1996); $100 \mathrm{~m}^{3} \cdot \mathrm{s}^{-1}$ in 2 sections $(1 \mathrm{~km}$ and $6 \mathrm{~km}$ downstream of the dam) in May 1995 (Lacaux and Delmas 1995). At $220 \mathrm{~m}^{3} \cdot \mathrm{s}^{-1}$ the measured emission fluxes of DM are rather well described at all the 5 points by the equation $\mathrm{F}=0.075 \mathrm{M}$, with F flux $\left(\mathrm{g} \cdot \mathrm{m}^{-2} \cdot\right.$ hour $\left.^{-1}\right)$ and $\mathrm{M}$ the DM concentration in the river which was in the 0.1-0.6 $\mathrm{mg} \cdot \mathrm{L}^{-1}$ range, whereas the equation $\mathrm{F}=0.02 \mathrm{M}$ is better suited for the 2 measurements points at $100 \mathrm{~m}^{3} \cdot \mathrm{s}^{-1}$ (Gosse et al. 1998).

Using the formula of $\mathrm{H}$ given here above and using the 2 formulae of $\mathrm{F}$ at $100 \mathrm{~m}^{3} \cdot \mathrm{s}^{-1}$ and $220 \mathrm{~m}^{3} \cdot \mathrm{s}^{-1}$ - with an interpolation for intermediate discharges - Gosse et al. (2002) proposed the following schematic model for the average DM disappearance in the river between the dam and Pointe Combi over the 1994-1998 period.

$$
\mathrm{dM} / \mathrm{dt}=-\mathrm{K}_{2} \mathrm{M}-\mathrm{D}_{3}
$$

with

$\mathrm{M}\left(\mathrm{mg} \cdot \mathrm{L}^{-1}\right)=\quad \mathrm{DM}$ concentrations in the river (considered homogeneous in the cross section, which is an acceptable hypothesis except for the first kilometres when there is a mixing of turbined flow with water coming from the bottom gates) 
$\mathrm{T}(\mathrm{s})$, time $=$

the time needed to cross the dam-Pointe Combi stretch being described by the equation $\mathrm{T}$ (in days) $=66 \mathrm{Q}^{-0.75}$; and the dilution effect of downstream tributaries being neglected, as their total flow generally represents less than $5 \%$ of $Q$

$\mathrm{K}_{2}\left(\mathrm{~s}^{-1}\right)=\quad$ coefficient of physical exchanges of methane at the water-atmosphere interface, equal to $0.075 / \mathrm{H}$ at $220 \mathrm{~m}^{3} \mathrm{~s}^{-1}\left(\mathrm{~K}_{2}=0.41 \cdot \mathrm{d}^{-1}\right)$

$\mathrm{D}_{3}\left(\mathrm{mg} \cdot \mathrm{CH}_{4} \cdot \mathrm{L}^{-1} \cdot \mathrm{s}^{-1}\right)=\mathrm{DM}$ loss due to $\mathrm{DM}$ oxidation inside the water column, which is calibrated, by reducing the discrepancy between the calculated and typical measured profiles of DM along the river during the 1994-1998 period.

Using the model, it was assessed (Gosse et al. 2002) that for the 19951998 period, close to $30 \%$ of the DM present in the river downstream of the aerating weir was emitted to the atmosphere for a turbined discharge between $220 \mathrm{~m}^{3} \cdot \mathrm{s}^{-1}$ and the mean annual discharge of the Sinnamary $\left(260 \mathrm{~m}^{3} \cdot \mathrm{s}^{-1}\right)$, the rest being oxidized inside the water column. It appeared that the formulation $\mathrm{D}_{3}=\mathrm{d} \cdot \mathrm{M}_{0}$, with $\mathrm{d}$ (constant approaching 0.6. $\mathrm{d}^{-1}$ ) and $\mathrm{M}_{0}$ (the upstream DM concentration) was a rather acceptable simplified formulation to describe DM oxidation and the longitudinal decrease in DM concentrations, in conjunction with the $\mathrm{K}_{2}$ formulation derived from the emission measurements of the GHG team and the very schematic hydrodynamics chosen in the model.

The percentage of DM which is emitted to the atmosphere downstream of the weir is much more important since end of 1999. The analysis of the longitudinal DM profiles collected by Hydreco shows that since that date, DM remains significantly present at Pointe Combi $\left(0.2 \mathrm{mg} \cdot \mathrm{L}^{-1}\right.$ or more at the dry season), even for discharges lower than $200 \mathrm{~m}^{3} \cdot \mathrm{s}^{-1}$, which did not happen the years before for similar levels of DM in the Sinnamary, in the near downstream of the aerating weir (Fig. 22.11). As there is no reason why the aeration coefficient at the surface should be lower from 1999 (on the contrary it could be slightly higher due to the improvement of the water quality over the years), the persistence of DM suggests a lower speed of DM oxidation in the river, which could be due to a lower population of active methanotrophic bacteria coming from the reservoir. The hypothesis of a new benthic production of methane is not considered as it would lead to worse DO conditions, which is not the case.

There are two direct consequences of the downstream persistence of DM in the river since end of 1999: firstly, it means that for a same flow 


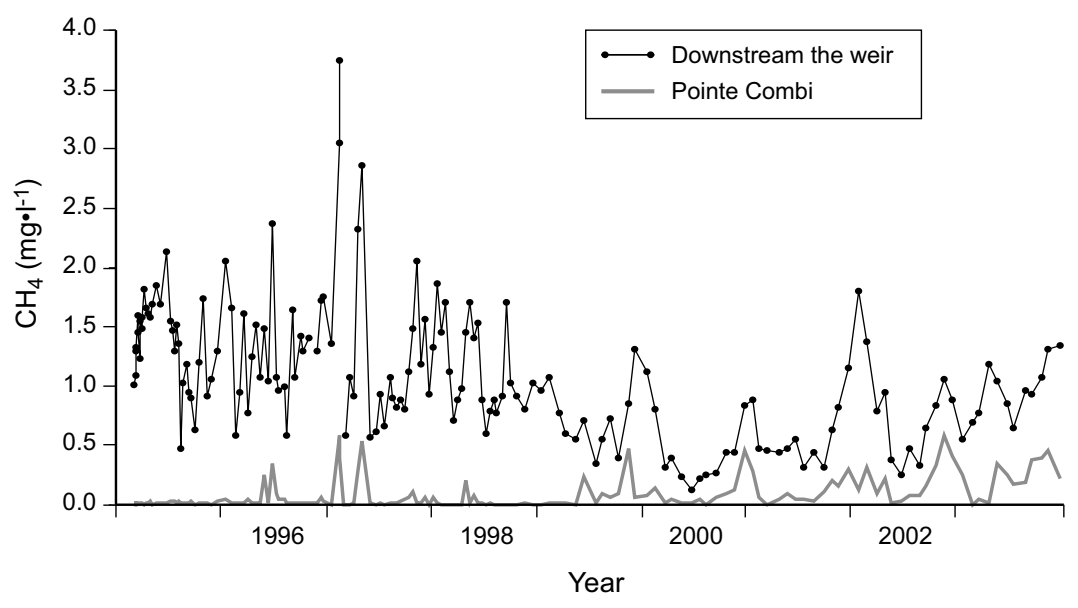

Fig. 22.11. Dissolved methane concentrations $\left(\mathrm{mg} \cdot \mathrm{L}^{-1}\right)$ downstream of the aerating weir installed in the power plant outlet canal and at Pointe Combi (40 km downstream of the dam). A general progressive decrease is observed after 1997 at the upstream point due to an improvement of water quality in the reservoir. The increase at this point after 2001 is due to the partial lowering of the aerating weir (end of 2001 and end of 2002). The dissolved methane concentration at Pointe Combi is greater after 1998 due to a decrease in the methane oxidation velocity along the river stretch

discharge and for a same concentration of DM downstream of the aerating weir, the DM flux emitted to the atmosphere in a downstream cross section is greater today than before end of 1999. The potential stock of DM which can be emitted to the atmosphere is less subject to a decrease by oxidation; secondly, it means that the aeration conditions at the surface downstream of Crique Venus - an area which was not studied by the GHG team as there were DM depleted at the time - are much more important today than before for correctly assessing the DM flux emitted to the atmosphere downstream of the dam: this is an area where the aeration at the surface is more and more influenced by tidal currents and wind action and imperfectly described by the flow discharges released by the dam.

DM emissions to the atmosphere and associated DM concentrations in the river were recently measured during a joint Hydro-Québec-HydrecoCNRS-EDF campaign performed one day of May 2003 for a $150 \mathrm{~m}^{3} \cdot \mathrm{s}^{-1}$ discharge (emission measurements given by A. Tremblay, L. Varfalvy, G. Abril and F. Guérin, oral communication). Three points of the river were studied. In the upper stretch of the downstream river (between 1 and $2 \mathrm{~km}$ downstream of the dam), the measured emission flux is coherent with the 1995 measurements: the adjustment of the coefficient $\mathrm{k}$ in the formula 
$\mathrm{F}=\mathrm{kM}$ giving the DM emitted flux $\mathrm{F}\left(\mathrm{g} \cdot \mathrm{m}^{2} \cdot \mathrm{h}^{-1}\right)$ from the DM concentration in the river $\left(\mathrm{M}\right.$ in $\left.\mathrm{mg} \cdot \mathrm{L}^{-1}\right)$ gives a value of $\mathrm{k}$ between 0.04 and 0.045 in the near downstream of the dam and at Crique Venus respectively for the May 2003 campaign, which is an intermediate value of those obtained at $100 \mathrm{~m}^{3} \cdot \mathrm{s}^{-1}$ and $220 \mathrm{~m}^{3} \cdot \mathrm{s}^{-1}$ in 1995 . At the third point (Pointe Combi), $\mathrm{k}$ appeared to be greater - close to 0.1 - under the influence of active wind and tide action, due to the proximity of the sea.

On the basis of the high value of $\mathrm{k}$ obtained in the downstream part of the river (Pointe Combi) for the June 2003 campaign, which is higher than the $\mathrm{k}$ values obtained along the dam-Crique Venus stretch during the 1995 campaign at $220 \mathrm{~m}^{3} \cdot \mathrm{s}^{-1}$, it can be calculated - using and Gosse et al.'s model with adapted values of $K_{2}$ and $d$ - that at least $45 \%$ of the DM flux present in the river downstream of the aerating weir was emitted to the atmosphere over the 2001-2002 period for the mean flow discharge along the $40 \mathrm{~km}$ downstream stretch. This is directly linked with the decrease of the oxidation velocity. Since end of 2001, this higher downstream emission tends to compensate the reduction in DM emission at the aerating weir, whose height was reduced.

\subsubsection{A New Assessment of the Methane Emissions to the Atmosphere in the Downstream Sinnamary River (1994-2002 Period)}

From the assessment of the DM flux crossing the Petit Saut dam (Chap. 4.3) and the DM flux emitted to the atmosphere donwnstream of the dam in the immediate (Chap. 4.4) and far (Chap. 4.5) fields, it is possible to propose an assessment of around 250000 tonnes for the methane emissions to the atmosphere in the downstream Sinnamary over the 1994-2002 period, and an assessment of around 40000 tonnes for the methane fluxes oxidised in the downstream river. This oxidation generates dissolved $\mathrm{CO}_{2}$ but this production is not sufficient by comparison to the aeration exchanges at the surface to provoke an increase of dissolved $\mathrm{CO}_{2}$ concentrations along the river, which, according to Hydreco measurements, were equal on average to $13.5 \mathrm{mg} \cdot \mathrm{L}^{-1}$ and $11.5 \mathrm{mg} \cdot \mathrm{L}^{-1}, 0.8 \mathrm{~km}$ and $40 \mathrm{~km}$ (Pointe Combi) downstream of the dam over the January 1999September 2001 period, a.

It can be considered that the constant value of $85 \%$ selected by GalyLacaux et al. (1997) and Delmas et al. (2001) - in their GHG emissions forecasts - for the percentage of DM emitted to the atmosphere from the downstream discharges of the dam, is rather acceptable on average over the 9 years 1994-2002 period (floods excluded), with the poorest represen- 
tativity for the first 14 months, during which DM emission was much greater as the bottom gates were mostly used to feed the downstream Sinnamary.

\subsubsection{Extrapolation of $\mathrm{CH}_{4}$ Findings to Other Morphological Conditions}

There are reasons to suggest that the building of the weir which locally increased the methane emissions to the atmosphere has not increased significantly the total downstream emissions of DM to the atmosphere, as it favoured DM oxidation by methanotrophic bacteria in the downstream river. Without specific effort to maintain the river oxygenated when turbining, i.e. without weir building in the plant outlet canal, the downstream river would have been anaerobic most of the time of the 1994-2002 period. Consequently no major methane oxidation would have taken place along the dam-Pointe Combi stretch., favouring an emission to the atmosphere of around half of the upstream DM flux.. Due to the high stock of DM which would have entered the estuary (around 2-3 $\mathrm{mg} \cdot \mathrm{L}^{-1}$ on average), high DM emissions to the atmosphere would have been present in the estuary at the surface due to wind and tide currents. The DO depletion in the river and intermittently at the bottom of the estuary would probably have led to DM production in the water column, probably generating an additional source of DM emission to the atmosphere.

If the slope of the downstream river had been very steep, no aerating weir would have been necessary to increase DO concentrations. The physical exchanges of gases at the water-air interface would have been naturally very high, with a rapid emission of DM to the atmosphere and an insignificant DM disappearance by oxidation, despite the better conditions for atmospheric oxygenation of the river and consequently better conditions for DM oxidation.

\subsubsection{The Role of DM Oxidation in the DO Budget of the Downstream Sinnamary}

DM started to play a major role in DO consumption during the short turbining tests performed between June and September 1994 (Chap. 22.4.4). Before that, the discharge was only released by the bottom gates which were delivering a water with less than $0.1 \mathrm{mg} \cdot \mathrm{L}^{-1}$ of DM, if we consider the DM content downstream of the bottom gate outlet in September 1994 $\left(0.2 \mathrm{mg} \cdot \mathrm{L}^{-1}\right)$ and the average DM concentration of $0.3 \mathrm{mg} \cdot \mathrm{L}^{-1}$ on the vertical in the reservoir in March 1994 (Gosse et al. 2000). The DO decrease of 
3 to $4 \mathrm{mg} \cdot \mathrm{L}^{-1}$ from the dam to Pointe Combi during the March-May 1994 period was generated by a chemical and biological consumption which was not linked to gases.

From October 1994 to February 1995, the DM concentration just downstream of the dam (water coming only from the bottom gates) gradually increased and reached $0.45 \mathrm{mg} \cdot \mathrm{L}^{-1}$ at the end of the period (Fig. 22.12). From March 1995 to March 1998, with the power station in operation and the aerating weir in place, the DM concentration just downstream of the weir was close to $1.3 \mathrm{mg} \cdot \mathrm{L}^{-1}$ on average (Fig. 22.11), representing a potential DO demand exceeding $4 \mathrm{mg} \cdot \mathrm{L}^{-1}$ on average. As the non-methanerelated chemical and biological consumption of oxygen has further decreased in the water released by the dam (assessed experimentally at less than $2 \mathrm{mg} \cdot \mathrm{L}^{-1}$ in 2 days), oxidation of DM has been considered as a major DO sink in the downstream Sinnamary from March 1995 to 1998 (Gosse et al. 2000). However, using a DO model which takes into account the aeration mechanisms at the surface, it was shown (Gosse et al. 2002) that a DO demand which was not experimentally detected in the dam outlet had to be added, in order to correctly reproduce the DO concentrations at Pointe Combi. (Fig. 22.13). The nature of this additional DO sink which was represented as a benthic demand (with possible values exceeding $2 \mathrm{~g} \cdot \mathrm{O}_{2} \cdot \mathrm{m}^{-2} \cdot \mathrm{d}^{-1}$ ) in a modelling exercise (Gosse et al. 2002) still has to be determined. It can be both benthic and contained in the flow, and is linked to the degradation of non volatile compounds released by the dam. The moderate level of the 2 days BOD measured at Pointe Combi $\left(1.2 \mathrm{mg} \cdot \mathrm{L}^{-1}\right.$ on average in $2002-2003$ at $25^{\circ} \mathrm{C}$ ) - which is lower than $0.8 \mathrm{~km}$ downstream of the dam (1.7 mg. $\mathrm{L}^{-1}$ on average) suggests that the non benthic sink cannot be very high.

DM played a lesser role in the DO budget of the downstream river after 1998 for 2 main reasons: general decrease in DM concentration in the reservoir and consequently downstream of the dam (before lowering the aerating weir); decrease in the DM oxidation velocity.

\subsection{General Conclusion}

Dissolved methane, which in a tropical environments had not been studied very closely until the last few years, has proven to be one of the most important parameters in terms of oxygen consumption and GHG emission at Petit Saut site.

The originality was the installation of a weir downstream of the turbines to reoxygenate the anoxic waters and to expulse methane in order to 


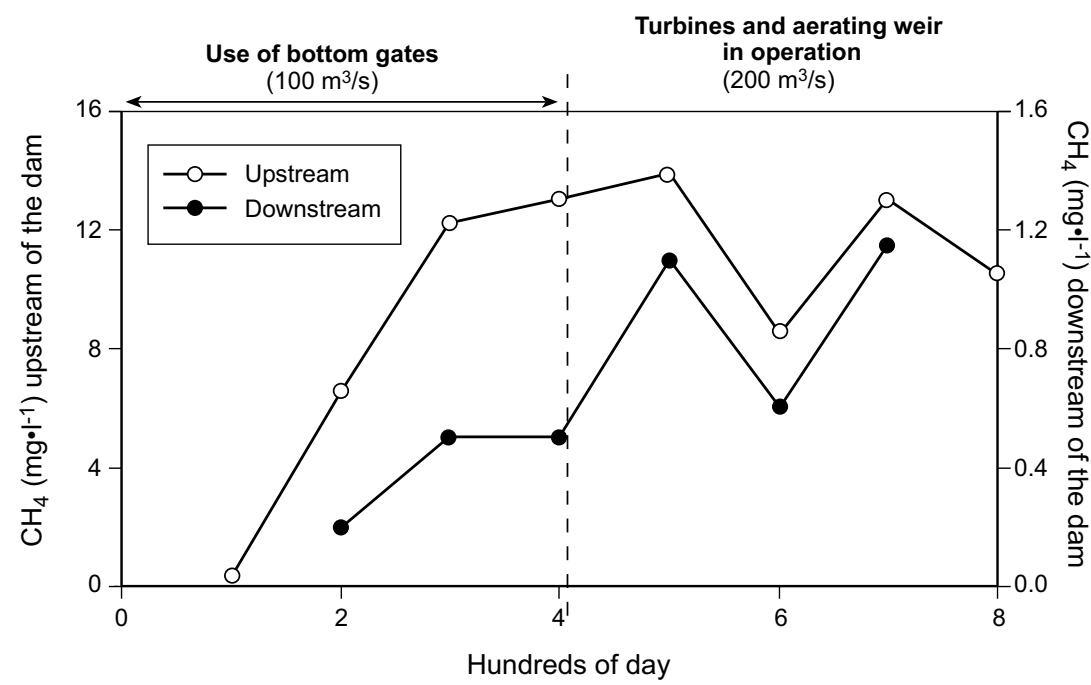

Fig. 22.12. Dissolved methane ( $\mathrm{mg} \cdot \mathrm{L}^{-1}$ ) upstream the dam (water column average) and in the Sinnamary 300m downstream of the dam, in 1994 and 1995 (in hundreds days from January 1994)

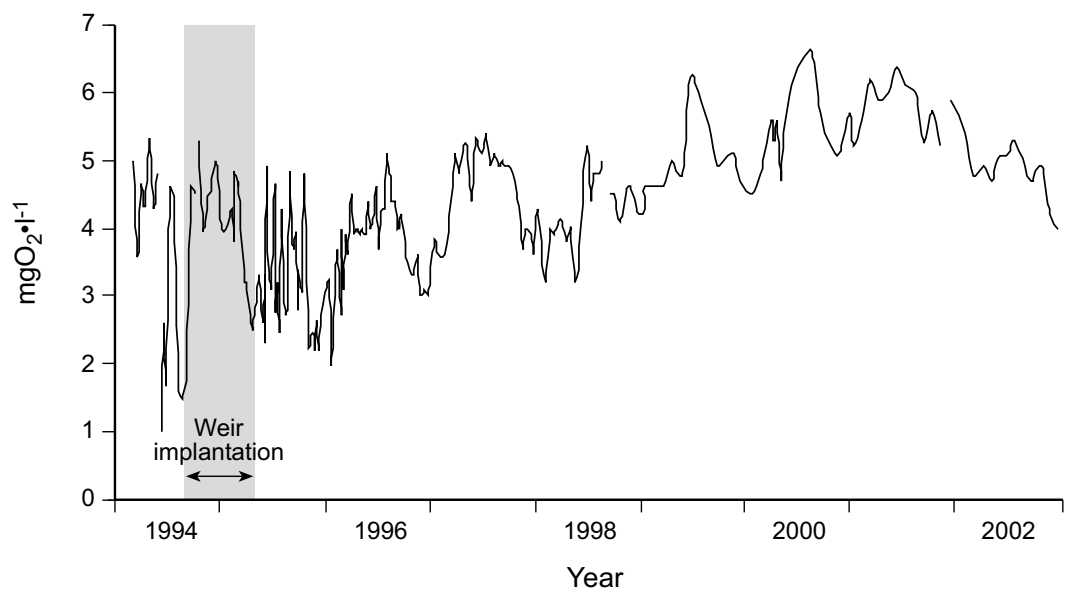

Fig. 22.13. Dissolved oxygen (DO) in $\mathrm{mg} \cdot \mathrm{L}^{-1}$ at Pointe Combi (from 1994 to 2002). Thanks to the weir built in the plant outlet canal which brought DO and eliminated dissolved methane (and its damaging oxidation) a concentration of $2 \mathrm{mg} \cdot \mathrm{L}^{-1}$ of DO was guaranteed. The general progressive increase from 1996 is correlated with the decrease in the consumed quantity of methane (Fig. 22.11). The decrease after end of 2001 is due to the lowering of the weir which has slightly reduced the DO upstream concentration and increased the methane content 
reduce its oxygen demand in the downstream river and guarantee the dissolved oxygen threshold of $2 \mathrm{mg} \cdot \mathrm{L}^{-1}$ determined for the maintenance of aquatic life in the Sinnamary. The oxygen demand of the remaining methane has decreased the last years, offering possibilities for lowering the weir.

The long term acquisition of information inside and downstream of the Petit Saut reservoir helps in detecting changes over time (DO and DM improvements in the reservoir and resulting DM emissions, DM oxidation velocity in the downstream river). In conjunction with data collection on older reservoirs, it will allow an improvement in the forecasts of aquatic ecosystems functioning and evolution in tropical reservoirs.

\section{Acknowledgements}

We thank all the Hydreco staff and specially Cécile REYNOUARD and Benoit BURBAN for technical supports; and EDF for its constant financial support to the environmental measurement programme. 